$1-1-1951$

\title{
West Virginia limestone : a calcium supplement for poultry
}

T. B. Clark

Follow this and additional works at: https://researchrepository.wvu.edu/ wv_agricultural_and_forestry_experiment_station_bulletins

\section{Digital Commons Citation}

Clark, T. B., "West Virginia limestone : a calcium supplement for poultry" (1951). West Virginia Agricultural and Forestry Experiment Station Bulletins. 345.

https://researchrepository.wvu.edu/wv_agricultural_and_forestry_experiment_station_bulletins/347 @ WVU. It has been accepted for inclusion in West Virginia Agricultural and Forestry Experiment Station Bulletins by an authorized administrator of The Research Repository @ WVU. For more information, please contact ian.harmon@mail.wvu.edu. 


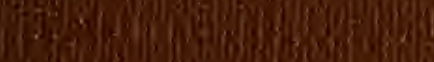

9.

5. 8 .

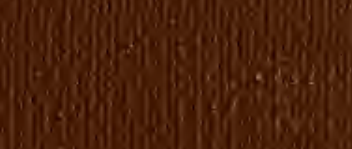

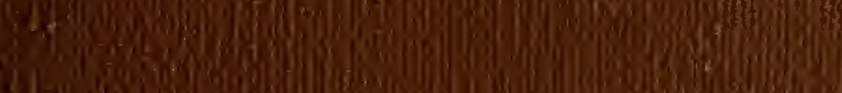

15. (2)

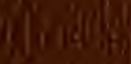

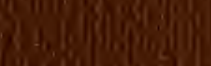

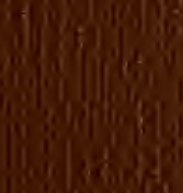
10 (19)

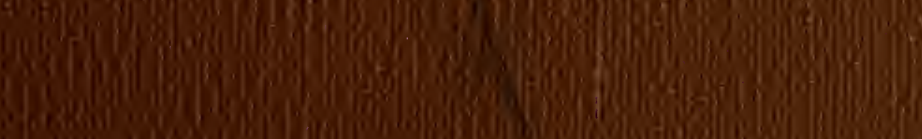

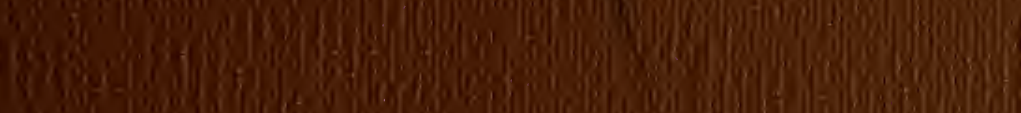
(i) 


\section{Digitized by the Internet Archive in 2010 with funding from Lyrasis Members and Sloan Foundation}




\section{West Virginia Limestone--}

\section{A}

\section{Calcium Supplement}

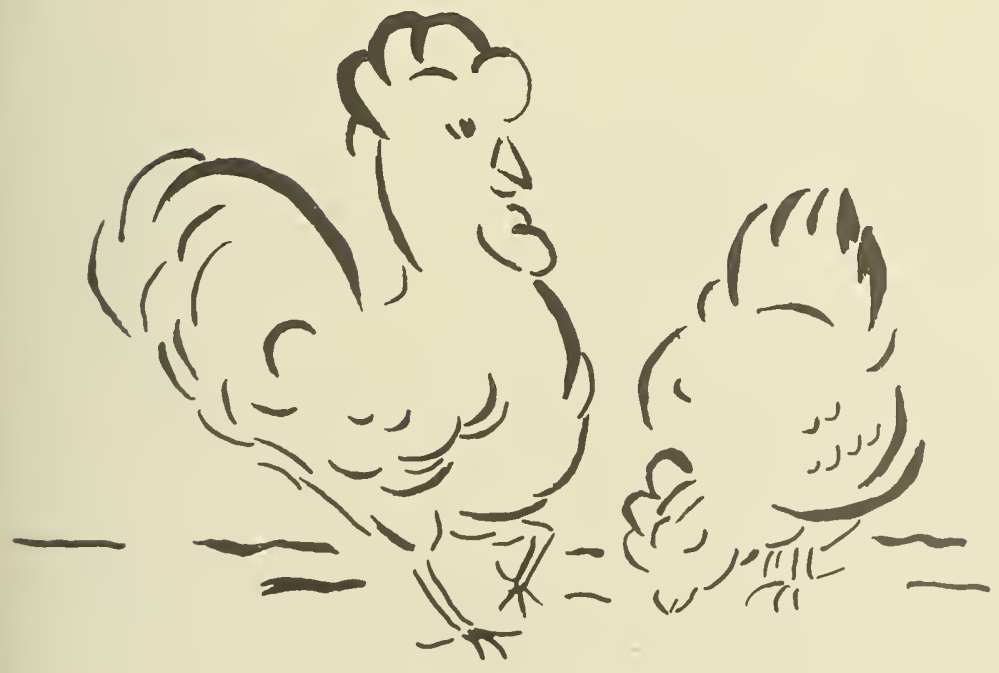

\section{For Poultry}

6

$\overline{2}$

WEST VIRGINIA UNIVERSITY

AGRTCULTURAL EXPERIMENT STATION 
T. B. CLARK is Associate Poultry Husbandman of West Virginia University Agricultural Experiment Station and Associate Professor of Poultry Husbandry in the College of Agriculture, Forestry, and Home Economics.

H. M. HYRE is Associate Poultry Husbandman of West Virginia University Agricultural Experiment Station and Associate Professor of Poultry Husbandry in the College of Agriculture, Forestry, and Home Economics.

C. E. WEAKLEY, JR. is Associate Agricultural Biochemist of West Virginia University Agricultural Experiment Station.

A. H. VAN LANDINGHAM is Assistant Director of West Virginia University Agricultural Experiment Station and Assistant Dean of the College of Agriculture, Forestry, and Home Economics.

West Virginia University

Agricultural Experiment Station

College of Agriculfure, Forestry, and Home Economics H. R. Varney, Director Morgantown 


\title{
WEST VIRGINIA LIMESTONE--
}

\section{A CALCIUM SUPPLEMENT FOR POULTRY}

\author{
T. B. Clark, H. M. Hyre, C. E. Weakley, Jr., and A. H. VanLandingham
}

West Virginia has plenty of limestone that might be suitable for poultry feeding if properly sized.

Much of this limestone contains less than 90 per cent of calcium carbonate. In the light of some experimental work the feeding value of this limestone might be questioned. West Virginia poultrymen have other arguments against its use. Some believe that hens do not readily consume the native dull-gray limestone. These poultrymen believe that the hens prefer the white, shiny calcitic limestone, an imported product. They also think that native limestone produces egg shells that are rough and sometimes weak. For many years poultrymen have preferred to feed oyster or other marine shells to their chickens. During World War II, however, the scarcity of such shells forced the use of calcitic limestone and some dull-gray limestone. Although calcitic limestone was found to be a satisfactory substitute, many poultrymen are still skeptical about the use of native dull-gray limestone.

Most of the published experimental work shows that crushed limestone containing 90 per cent or more of calcium carbonate is satisfactory for egg production. On the other hand, feeding of very lowcalcium limestones did, in most experiments, result in a lower egg production compared with that obtained from high-calcium limestones. In some cases the health of the birds fed dolomitic limestones was impaired. None of the experiments reported in the literature gave sufficient evidence that high-grade limestone produces poor shell quality, but several indicated that the dolomitic limestones reduced shell strength.

Of particular interest to West Virginia poultrymen is an experiment reported by Waite (1935) of the Maryland Experiment Station. In this experiment a blue limestone quarried at Morgantown, West Virginia, was compared with oyster shells. Egg production and shell 
strength were similar in all lots, but the birds consumed more oyster shells than limestone. This investigator found that hens usually ate more of the oyster shells than they needed. They expelled that portion not required for egg-shell formation with the droppings. This appears to answer the question that has puzzled experimenters as to how hens can maintain egg production on a lesser consumption of limestone than of oyster shells. Waite stated that the manufacturer of the blue limestone was forced to remove it from the market because poultrymen complained that the layers would not consume enough of this dark-colored limestone.

The arguments against use of dull-gray limestone by West Virginia poultrymen did not seem to be supported by much experimental evidence. However, there was no first-hand information available on the value of native limestone. Although other experiment stations were recommending limestone containing 90 per cent or more of calcium carbonate, much of that quarried in West Virginia contained less than 90 per cent and was considered to be of questionable value as a calcium supplement for poultry feeding. In addition, there was some confusion in the minds of poultrymen concerning the value of grit because crushed limestone is commonly called limes tone grit.

\section{EXPERIMENTAL RESULTS FROM LAYING TRIALS}

Procedure. The laying trials were started in 1945. New Hampshire pullets were used. In the two following years, both New Hampshire and White I eghorn pullets were used. These trials were conductec in a long-type laying house divided into pens, 20 by 20 feet. Conditions were alike for all pens. The New Hampshire pullets wer divided into four groups according to strain and body weight for the first two years and to dam and body weight for the third year. Thi Leghorn pullets were divided according to dam, body weight, an date of hatch for both years.

The 1945-46 New Hampshire pullets were fed an all-mash ration containing whole oats. In the two following years a 20 per cent prc tein mash was fed to both breeds of pullets. Scratch grain compose of corn, wheat, and oats were fed to the pullets in measured amounts the grain was fed so that the pullets consumed 40 per cent of corn an wheat to 60 per cent of oats. The total amount of grain fed was base on the amount of mash consumed the previous day. The pullets wer forced to consume the ration in the proportion of 40 parts of grain 60 parts of mash.

The limestone was obtained from quarries in Monongalia and Ber 
eley counties. Grade $12 \mathrm{~A}$ was used, 100 per cent of which passes through a $3 / 8$ inch screen, 95 per cent through a $1 / 4$ inch screen, and 20 per cent passes through a $1 / 8$ inch screen. There is some fine material in this grade that laying chickens will refuse, but not enough to be a serious problem. The calcium carbonate content was about 35 and 90 per cent for the Monongalia and Berkeley County limestones, respectively. The calcitic limestone was No. 3, the size commonly used for adult chickens. It was quarried in Maryland and purchased on the open market in-West Virginia.

A statistical analysis was made of all data summarized in the tables.

\section{EGG PRODUCTION}

Native Limestone vs, Oyster Shells and Calcitic Limestone. In all laying trials the egg records were not considered until the sullets had been on the treatments for one experimental period. The umber of pullets that were started, the number that died, and the veights are given in Table 1. The pertinent data on egg production and feed consumption are given in Table 2 and Table 3 for the New fampshire and White Leghorns, respectively.

The two native limestones studied were compared with oyster shells and calcitic limestone in 1945-46 (Table 2). This trial was conlucted for six, 28 day periods. Lots 1 and 3, fed the native limestones, averaged to lay about the same number of eggs, but these averages were lower than those for Lots 2 and 4. The differences are highly significant. These real differences suggest that the limestones used were inferior to the other calcium supplements. Certainly the differences were not caused by the layers refusing to eat these limestones. The layers in Lots 1 and 3 ate more limestone per period or per dozen -ggs than did those fed oyster shells or calcitic limestone. These esults could have been influenced by other conditions, as suggested n a later experiment with this breed. It should be remembered that the sullets used in these trials were not pedigreed according to dam and nay not have been uniformly distributed. Furthermore, the treatments vere not replicated. Too, the consumption of limestone may have been :xcessive.

The 1946-47 trial with White Leghorns, Table 3, was conducted o provide a more critical comparison of native limestone containing tbout 90 per cent calcium carbonate with oyster shells. Four lots of sedigreed White Leghoms were used. The lots were paired so that :ach pair contained pullets from the same dam. Each dam's offspring 
Table 1. Number of pullets, the mortality, and their average body weights.

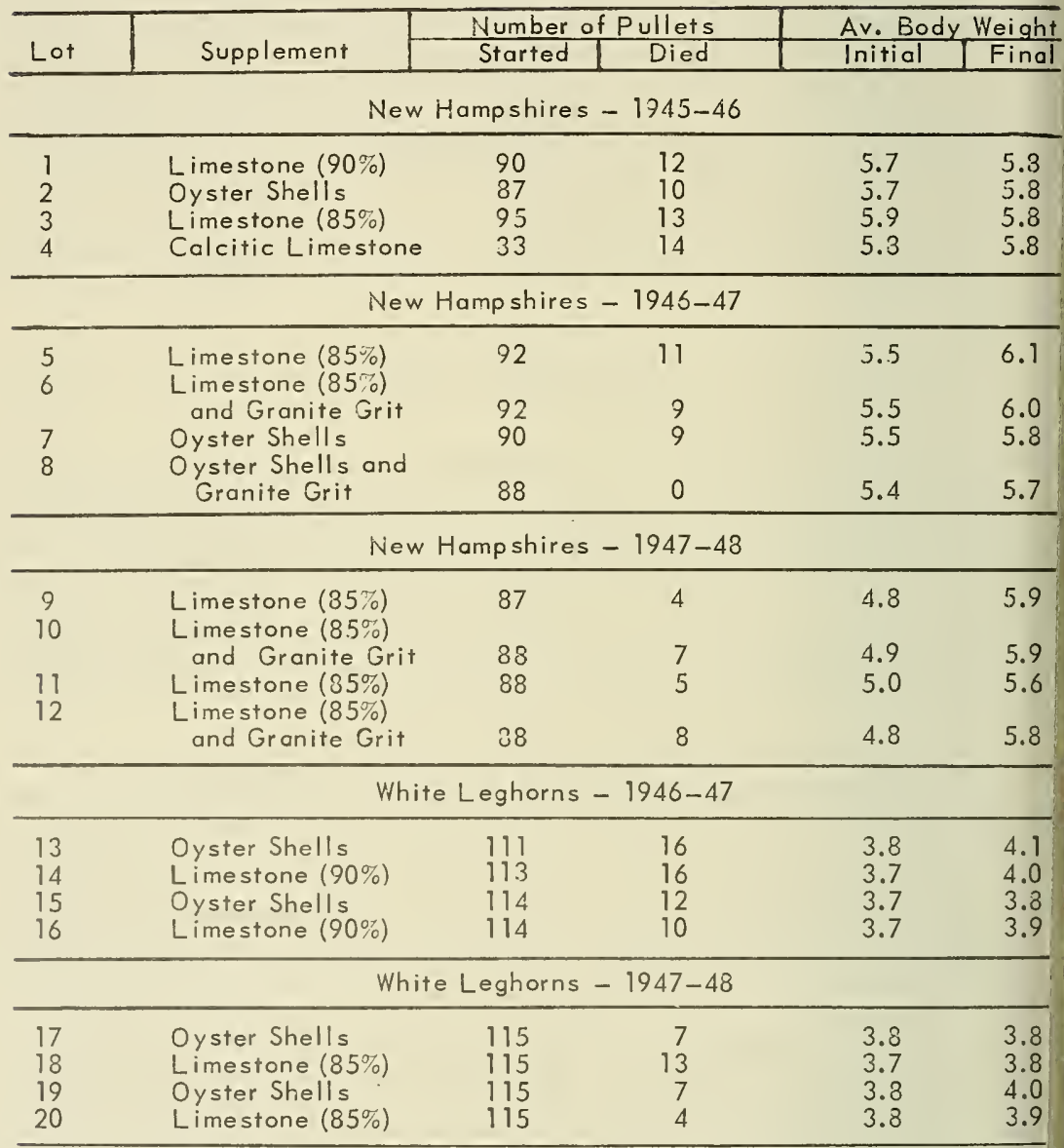

were distributed between each pair of lots according to body weight at date of hatch. Except for the different calcium supplements, all lo were fed and managed alike.

The average egg production values for each pair of lots are almo identical. Egg production values for Lots 13 and 14 are higher th: those for Lots 15 and 16. The only explanation for this seems to the age difference. The first two lots contain pullets from the eas hatches.

The 1947-48 trial with White Leghorns, Table 3, was conducted provide more information on a local limestone containing about 85 f cent calcium carbonate. The pullets were distributed between the fit 


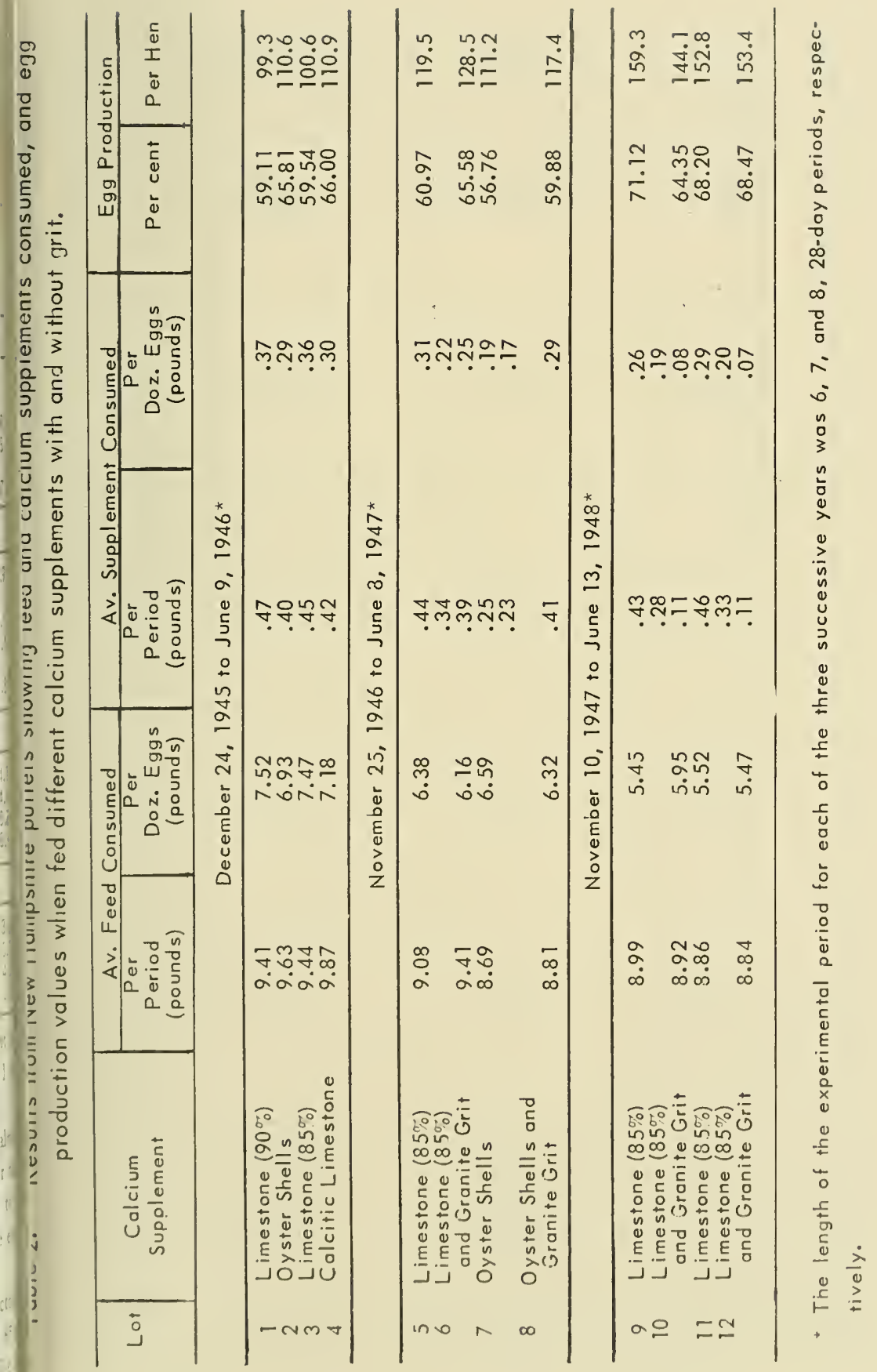




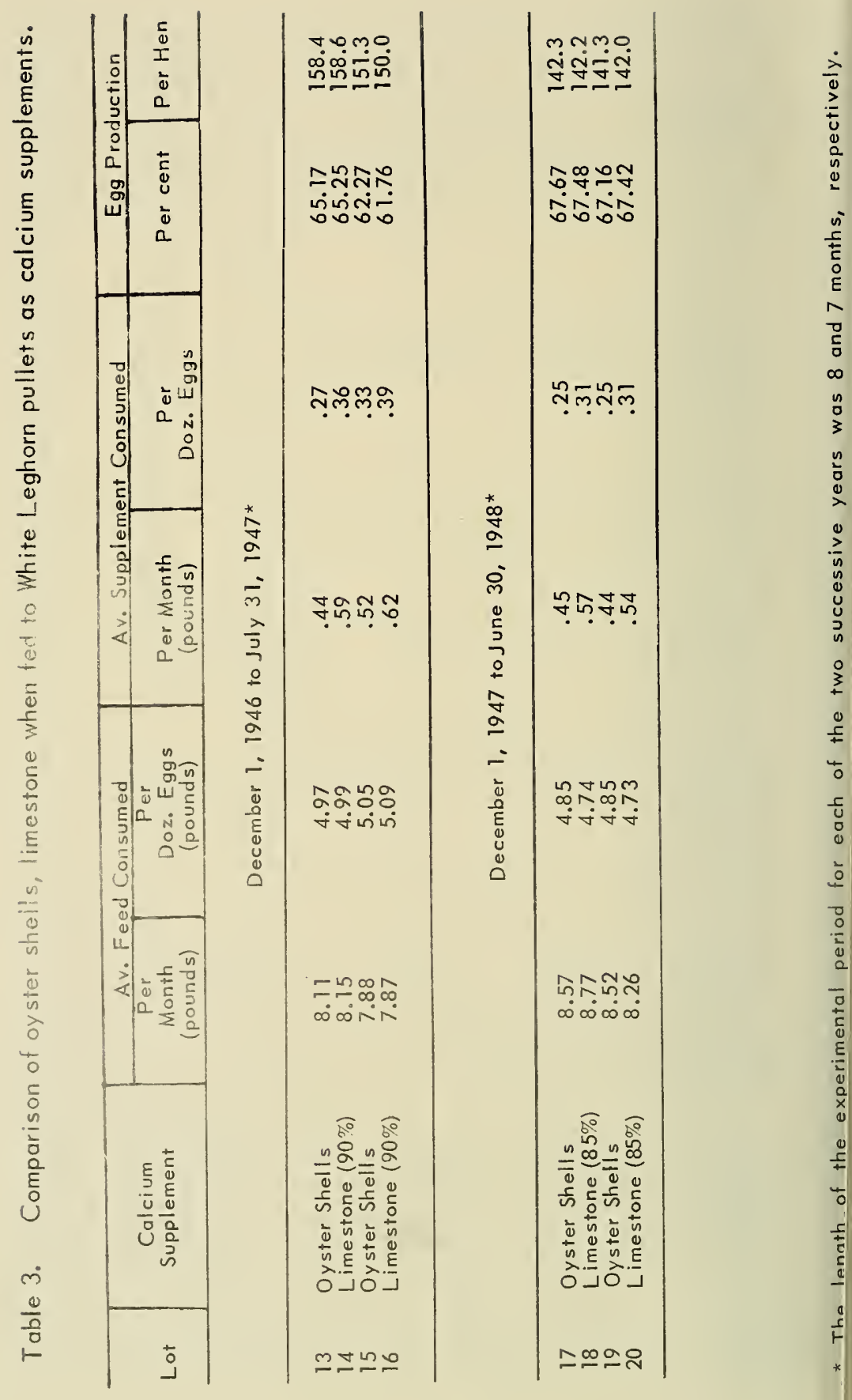


ots according to dam, pedigree, and hatch. Results of this trial show hat egg production for all lots was alike. The pullets laid as many :ggs when fed native limestone containing 85 per cent calcium carinate as they did when fed oyster shells. The egg production values ire remarkably uniform. The difference in egg production between the wo years is due largely to a shorter experimental period of seven nonths in the latter year compared with eight months in the former ear.

The Effect of Grit. Calcitic limestone often is considered to funcion in the dual capacity of furnishing calcium and acting as a grinding igent. Of course, it breaks down more readily than a granite grit or iver pebbles. Nevertheless, it was of interest to determine if the ative limestones would serve reasonably well for both purposes. To btain this information a series of trials were started. The 1946-47 rial with New Hampshire pullets was conducted to compare native imestone and oyster shells with and without granite. Both supplements rere kept continuously before the pullets.

Results in Table 2 show that the pullets with access to grit (Lots and 8) laid significantly more eggs than those without grit (Lots 5 nd 7). Also, the lots fed the limestone laid significantly more eggs han those fed oyster shells. The higher egg-producing lots proved , be more efficient in the utilization of feed on a per-dozen basis.

The pullets that had access to granite grit ate large quantities of In fact, they ate more grit than they did oyster shells or limestone. his surprising result might have been caused by a deficiency in the iet or by the hens' inability to differentiate between these calcium upplements and the granite grit. However, the granite grit may have een more attractive. Other workers have reported that certain colors ie attractive in grit, especially black specks.

Even though the pullets fed the granite grit laid more eggs than ose without this grit, its economic value still is open to question. he pullets ate such large quantities of the grit so that the additional ggs laid just increased the returns enough to slightly more than pay it the grit. To have any value when fed with West Virginia limestone, ranite grit should increase annual egg production more than 5 per cent. his is based on the prices at the time of this experiment.

One interesting result is that regardless of whether or not grit was : $d$, the lots fed limestone laid more eggs than those fed the oyster hell. Furthermore, the higher production was obtained from the 85 per ent limestone. This is strong evidence that such limestone produces atisfactory egg production. This trial also indicated that the Leghorns cilized the limestone no better than did the New Hampshires. 
The 1947-48 trials with. New Hampshires were conducted to obtair more information on the value of grit. The pullets had eaten larges quantities of grit in the previous trial than seemed to be justified Since the actual grit requirements were shown by Waite (1935) to bs lower than obtained here, it seemed advisable to restrict the grit. Ac cordingly, trials were set up using the same treatments as in 1946-47 The granite grit fed was restricted by opening the grit hoppers onl one day each week. Each treatment was replicated, and the pullet were distributed according to dam, pedigree, and hatch.

Results of the 1946-48 trials, given in Table 2, suggest that the feeding of granite grit one day each week had little or no effect o egg production. In fact, Lot 9, which did not receive granite grit, lai more eggs than did Lot 10, which had access to grit one day per week This is opposite of the results obtained in the previous year. In th other pair of pens the egg production values are almost alike. It $\mathrm{i}$ believed that the egg production in Lots 9 and 10 may have bee affected by something other than granite grit.

\section{SHELL QUALITY}

Several methods were compared to study the effects of varior calcium supplements on shell quality. During the first year a shor test and the percentage moisture loss methods were used. These we not found to be critical enough, so three other methods were studie during the laying year, 1947-48. They were (1) shell thickness, ( shell strength as indicated by a puncture method, and (3) the specif. gravity of the whole egg. The values obtained from either of the fir two methods were found to be highly correlated with those of the thi method. Actually, specific gravity measures shell density and is good indicator of shell quality. The specific gravity test was fou to be the best practical method for measuring differences in she quality. It was the easiest test to manipulate, and the eggs could marketed afterwards. Only the results from this test are reported hes.

\section{RESULTS FROM SPECIFIC GRAVITY TESTS}

Table 4 gives the specific gravity values. The results for $t$ White Leghorns, 1946-47, Lots 13 to 16, are for eggs laid during last five days of July. At this season egg shell quality is the poore, hence any good or bad effect should have been magnified from the fe ing of calcium supplements. Actually, no treatment effects were tained. The average specific gravities do not differ significantly. 
Table 4. Specific gravity of ejgs laid by pullets fed oyster shells or limestone.

\begin{tabular}{|c|c|c|c|}
\hline Lot & Supplement & $\begin{array}{c}\text { Number of Eggs } \\
\text { Tested }\end{array}$ & $\begin{array}{c}\text { Specific Grovity } \\
\text { of Eggs }\end{array}$ \\
\hline \multicolumn{4}{|c|}{ New Hompshires - 1947-48 } \\
\hline \multirow{4}{*}{$\begin{array}{c}9 \\
10 \\
11 \\
12\end{array}$} & \multirow{4}{*}{$\begin{array}{l}\text { Limestone }(85 \%) \\
\text { Limestone }(85 \%) \\
\text { and Gronite Grit } \\
\text { Limestone }(85 \%) \\
\text { Limestone }(85 \%) \\
\text { and Gronite Grit }\end{array}$} & 298 & 1.0846 \\
\hline & & 251 & 1.0837 \\
\hline & & 300 & 1.0841 \\
\hline & & 276 & 1.0845 \\
\hline \multicolumn{4}{|c|}{ White Leghorns - 1946-47 } \\
\hline $\begin{array}{l}13 \\
14 \\
1.5 \\
16\end{array}$ & $\begin{array}{l}\text { Oyster Shells } \\
\text { Limestone }(90 \%) \\
\text { Oyster Shells } \\
\text { Limestone }(90 \%)\end{array}$ & $\begin{array}{l}257 \\
255 \\
251 \\
240\end{array}$ & $\begin{array}{l}1.0750 \\
1.0751 \\
1.0760 \\
1.0772\end{array}$ \\
\hline \multicolumn{4}{|c|}{ White Leghorns - 1947-48 } \\
\hline $\begin{array}{l}17 \\
18 \\
19 \\
20\end{array}$ & $\begin{array}{l}\text { Oyster Shells } \\
\text { Limestone }(85 \%) \\
\text { Oyster Shells } \\
\text { Limestone }(85 \%)\end{array}$ & $\begin{array}{l}389 \\
431 \\
537 \\
576\end{array}$ & $\begin{array}{l}1.0874 \\
1.0859 \\
1.0870 \\
1.0871\end{array}$ \\
\hline
\end{tabular}

Eggs from both breeds were tested during the 1947-48 trials. Eggs vere saved for testing during two three-day periods in April, 1948. The values were averaged and are presented in Table 4 .

Comparing the Leghorns, the difference between the specific gravity alues for Lots 17 and 18 is highly significant. The reason for this $s$ not clear. It will be seen, however, that the same trend occurred setween Lots 9-10 and 13-1 ́. Apparently it was not a treatment diference but must have been caused by some error in the testing routine. Is in the previous trials with Leghorns, the second pair of lots beaved alike. These results then suggest that either the 85 or t!e 9? ier cent calcium carbonate limestone produced as good egg sliell fuality as did the oyster shells.

Tl:e results from the New Ilampshires, 1947-i8, are not presented o show an expected treatinent difference, but to show that the dillernce betueen the first pair of lots is in the same direction as the first air in each Leghorn trial. It also will be seen that the Leghorn eggs as a much higher specific gravity than the New I!ampshirc crobs for he year 19 $17-48$.

i hatever the reasons for the differences, there is no evidence from iis test that limestone produced an egg shell of lower density than did ie oyster shells. 


\section{BONE CALCIFICATION}

When this investigation on West Virginia limestone was being outlined, several members of both the feed and limestone industries wondered about the value of pulverized limestone for use in poultry mashes. Native limestone had been used for many years at the West Virginia University Poultry Farm as a calcium supplement in both chick and starting mashes. Apparently the results had always been satisfactory. When critical nutritional tests were conducted, however, oyster shell flour was used in place of the finely ground limestone. When the feeding value of the native limestone was questioned, the feeding trials reported here were planned.

The same limestones as used in the laying trials were finely ground and were compared with oyster shell flour in a chick starting ration. Chicks from a New Hampshire-Barred Rock cross were used so as to determine sex at day-old. Ten chicks were grown on each ration in each series to three weeks of age in starting batteries. At this age, five chicks of each sex from each lot were sacrificed. The middle toes of each chick were removed and ashed according to the method of Baird and co-workers in 1942.

A basal ration of the following formula was used: Yellow corr meal 37.2 , ground wheat 15 , ground oats 16 , alfalfa meat 5 , soybear oil meal 27.7, Curbay B. G. 2.5 , salt $-\mathrm{MnSO}_{4} 0.5$, codliver oil conc. 0.1. The kind and amounts of calcium supplements added to thi: ration are shown in Table 5. Additional amounts of corn meal wer added as required to make 100 parts.

The percentage of toe ash is given on a dry weight basis. Thes percentages are pooled values for both sexes. Results show that $i$ both series the two sources of limestone provided as good bone cal cification as did the oyster shell flour. The reason for the low calc: fication in Lot No. 2 of both series is not clear, unless the additions amount of oyster shell flour unbalanced the Ca:P ratio.

Table 5. Per cent of toe ash in chicks when fed oyster shell floi or pulverized limestone as calcium supplements.

\begin{tabular}{c|c|c|c|r}
\hline & \multicolumn{2}{|c|}{ Series I } & \multicolumn{2}{c}{ Series 2 } \\
\hline Lot & $\begin{array}{c}\text { Calcium } \\
\text { Supplement }\end{array}$ & $\begin{array}{c}\text { Toe Ash } \\
\text { In Chicks }\end{array}$ & \multicolumn{1}{c}{$\begin{array}{c}\text { Calcium } \\
\text { Supplement }\end{array}$} & $\begin{array}{r}\text { Toe As } \\
\text { In Chic }\end{array}$ \\
\hline 1 & 1-Oyster Shell Flour & 10.68 & l-Oyster Shell Flour r & 10.4 \\
2 & 2 -Oyster Shell Flour & 7.92 & 2-Oyster Shell Flour & 9.9 \\
3 & 1-Limestone (85\%) & 10.62 & 2-Limestone (85\%) & 10.7 \\
4 & I-Limestone (90\%) & 11.04 & 2-Limestone (90\%) & 10.7 \\
\hline
\end{tabular}




\section{SUMMARY AND CONCLUSIONS}

West Virginia limestone was compared with oyster shells and cal:itic limestone as calcium supplements for poultry. In addition, the lative limestone for use as a grit was compared with granite grit. -imestones from two different quarries were used, one containing ibout 85 per cent and the other about 90 per cent of calcium carbonate.

Laying trials were conducted over a three-year period. White Legorn and/or New Hampshire pullets were used each year. The pullets vere housed in a well-insulated, long-type house containing eight ens, each 20 by 20 feet. The growth trials were conducted to comare the finely ground native limestone with oyster shell flour in tarting rations. The chicks were grown in batteries, and the comarison was made by the percentage of bone ash at three weeks of ge.

The results for the various trials are summarized as follows:

1. Properly-sized native limestone produced just as good egg roduction as did the oyster shells, with the exception of the first aying trial.

2. Shells of eggs laid by pullets fed native limestones were as trong and free from rough shells as were shells of eggs laid by ullets fed the other supplements tested.

3. Native dull-gray limestones tested were consumed as readily y the layers as oyster shells and calcitic limestone.

4. Bone calcification in three weeks old chicks was comparable when starting ration was balanced for calcium with either finely round limestone or oyster shell flour.

5. Limestone containing about 85 per cent of calcium carbonate roved to be as good, in the above respects, as the 90 per cent limetone in both growing and laying trials.

6. Additional eggs obtained from the lots fed granite grit slightly iore than paid for the large amounts of grit consumed.

The rcsults of the entire experiment seem to justify the following onclusions:

West Virginia limestone containing 85 per cent or more of calcium arbonate will, when properly sized, serve satisfactorily as a calcium upplement for growing and laying stock. A size comparable to the $2 \mathrm{~A}$ grade is satisfactory for hopper-feeding layers. For chicks, a nely-ground material should be added to the mash.

The value of feeding granite grit with these limestones is questionble. 


\section{ACKNOWLEDGEMENT}

The Berkeley County limestone was furnished by the Blair Limestone Division.

\section{REFERENCES}

Baird, F. D., and MacMillan, M. J., "Use of Toes Rather than Tibia" in A. O. A. C. Chick Method of Vitamin D Determination." Jour. inal of the Association of Official Agricultural Chemists, 25:518 $542,1942$.

Waite, R. H., Miscellaneous Studies on Poultry Grit. Mid. Agr. Exp. St: Bull. 377, 1935. 

